\title{
Conventional and Molecular Approaches towards Genetic Improvement in Pigeonpea for Insects Resistance
}

\author{
Arbind K. Choudhary ${ }^{1}$, Ranjeet Sharad Raje ${ }^{2}$, Subhojit Datta ${ }^{3}$, Rafat Sultana ${ }^{4}$, Timmanna Ontagodi ${ }^{5}$ \\ ${ }^{1}$ Indian Institute of Pulses Research, Regional Research Station Cum Offseason Nursery, Dharwad, India; ${ }^{2}$ Division of Genetics, \\ Indian Agricultural Research Institute, New Delhi, India; ${ }^{3}$ Indian Institute of Pulses Research, Kanpur, India; ${ }^{4}$ Department of Plant \\ Breeding and Genetics, Bihar Agricultural University, Sabour, India; ${ }^{5}$ Department of Genetics and Plant Breeding, University of \\ Agricultural Sciences, Dharwad, India. \\ Email: akiipr23@yahoo.com
}

Received December $18^{\text {th }}, 2012$; revised January $20^{\text {th }}, 2013$; accepted January $28^{\text {th }}, 2013$

\begin{abstract}
Pigeonpea [Cajanus cajan (L.) Millspaugh] is an important food legume of the semi-arid tropics (SAT) sustaining livelihood of millions of people. Stagnant and unstable yield per hectare all over the world is the characteristic feature of this crop. This is primarily ascribed to its susceptibility/sensitivity to a number of biotic and abiotic factors. Among biotic factors, insects such as pod borer (Helicoverpa armigera), pod fly (Melanoagromyza obtusa) and spotted borer (Maruca vitrata) substantially damage the crop and result in significant economic losses. Management of these insects by genetic means has always been considered environment friendly approach. However, genetic improvement has always been impeded by limited genetic variability in the primary gene pool of pigeonpea. Wild species present in the secondary and tertiary gene pools have been reported to carry resistance for such insects. However, transfer of resistance through conventional backcrossing has not been much successful. It calls for gene introgression through marker assisted backcrossing (MABC) or advanced backcross breeding ( $\mathrm{AB}$ breeding). In this review, we have attempted to assess the progress made through conventional and molecular breeding and suggested the ways to move further towards genetic enhancement for insects resistance in pigeonpea.
\end{abstract}

Keywords: Cajanus cajan; Insects Resistance; Wild Species; Secondary Gene Pool; MABC; AB Breeding

\section{Introduction}

Millions of people in the semi-arid tropics (SAT) are living below poverty line and their livelihood primarily depends on rainfed agriculture. Pigeonpea [Cajanus cajan (L.) Millsp.] plays an important role in sustaining the livelihood of poor people in the SAT regions by forming an integral component of rainfed agriculture [1]. It is a multi-purpose legume, which not only provides food and domestic fuel wood, but also enriches soil by improving water infiltration and conserving valuable nutrients and water. It is endowed with several unique features that allow its plants thrive well in drought prone degraded soils. Therefore, the cultivation of pigeonpea is likely to contribute to the overall economic development of the SAT regions by promoting a sustainable and eco-friendly agriculture that is subject to easy adoption by the resource poor farmers.

Pigeonpea is an often cross-pollinated diploid $(2 \mathrm{n}=2 \mathrm{x}=$ 22) crop with $833.07 \mathrm{Mb}$ genome size [2]. Globally, pigeonpea is cultivated on an area of $4.92 \mathrm{M}$ ha yielding a production of $3.65 \mathrm{Mt}$ with an average productivity of
$800 \mathrm{~kg} / \mathrm{ha}$ [3]. Besides India, Kenya, Uganda, Malawi, Tanzania, Myanmar, Nepal, Puerto Rico, Dominican Republic, and Venezuela are the major pigeonpea-producing countries. In India, it is mainly cultivated as rainfed crop in about 3.92 Mha, accounting for more than $80 \%$ of the global pigeonpea production. In the states of Maharashtra, Karnataka and Andhra Pradesh, which account for $>50 \%$ of the total pigeonpea area, pigeonpea is grown almost exclusively as a rainfed crop. From 1950 to 2010, the area under pigeonpea in India has increased from 2.18 to 3.92 Mha.

However, despite its importance in subsistence and sustainable agriculture and continued breeding efforts towards genetic improvement, the average global productivity of pigeonpea has remained static over the last three decades. The yield gap observed between the potential yield and on-farm yield is mainly due to prevalence of various abiotic [4] and biotic factors together with the cultivation of pigeonpea in marginal lands with low input supply and lack of efficient management practices [2]. There has been observed wide yearly fluctuations in total production mainly due to attack by insect pests including 
disease-causing pathogens.

More than 200 insect species have been reported to feed on pigeonpea from germination to harvest. However, a large number of insects attacking the crop do not cause significant loss [5]. Among the variety of insects feeding on pigeonpea, the pod borer (Helicoverpa armigera Hubner) is the most damaging pest worldwide, and its frequent occurrence often results in complete crop failure. It may alone cause losses to the tune of more than US $\$ 300$ million annually [6]. The wide host range, high degree of migration, indiscriminate pesticide application by farmers and innate ability of the insect to quickly develop resistance to applied insecticides have made it attain the status of the key pest $[7,8]$. This insect is panmictic and mobile; this leads to inter-mating of different geographic groups within the range of migration, resulting in high genetic variability within a population. The high genetic variability helps it evolve and adapt rapidly in different environments [9].

The other most damaging insect, which has been identified as one of the most important yield reducing factors, is the pod fly (Melanagromyza obtusa Malloch) [10], causing an annual loss of US \$256 million annually [6]. It causes an average of $34.5 \%$ pod damage, which in turn results in $29.8 \%$ grain loss [11]. Besides pod borer and pod fly, other insects like spotted borer/Maruca (Maruca vitrata Geyer) and pod sucking bugs (Clavigralla horrida Germar) pose a big threat to pigeonpea production [12]. Maruca is a serious insect pest of early pigeonpea; yield losses due to Maruca damage in pigeonpea ranged up to $100 \%$. The development of resistant cultivars and germplasm is one of the best means for controlling this insect [13]. Scale insect (Ceroplastodes cajani) has also been noticed to reduce yield of pigeonpea [14]. Resistance to storage pests such as bruchid (Callosobruchus spp.) and weevils (Callosobruchus chinensis) is also important in pigeonpea, and is lacking in cultivated species [15]. Infestations from such storage pests intensify the situation and result in profound seed damage during storage.

Identification and utilization of resistant cultivars against these insects would provide an environment-friendly solution and sustainable management of these insect-pests. In this paper, we have attempted to amass available literature on host resistance to these insets, and discussed the ways how best these can be utilized to develop resistant cultivars for improving yield stability in pigeonpea.

\section{Screening of Pigeonpea Genotypes for Insects Resistance}

A number of studies have been conducted to identify sources of resistance to various insects in pigeonpea. Thus far, however, only few genotypes have been documented as resistant in the cultivated accessions. In pi- geonpea, differential infestation specificity by insects has been reported due to a large variation in maturity period.

The extra short-duration varieties (that are harvested during October-November) and the medium-duration genotypes (which are harvested in December-January) are more severely damaged (as high as $90 \%$ in some years) by pod borer. The long-duration types, which mature from February onwards, tend to have lower podborer damage. Determinate types have heavier damage than the indeterminate types. "UPAS 120" (an indeterminate variety) is fairly tolerant, whereas "ICPL 151" (a determinate variety) is highly susceptible. More than 14,000 pigeonpea germplam accessions have been screened to identify the sources of resistance to pod borer, but only a few accessions with low levels of resistance have been detected [16]. Among the cultivated pigeonpea genotypes, "ICPL 332" (the resistant check) was consistently less damaged than the susceptible check "ICPL 87".

The high level of natural incidence of Maruca provides an opportunity for evaluation of pigeonpea germplasm under field conditions [13]. Screening of the germplasm accessions revealed a large variation in Maruca damage to flowers and pods. On an average, the damage in determinate accessions $(66 \%-75 \%)$ was higher than that of non-determinate accessions $(41 \%-50 \%)$. Selections for resistance to Maruca damage among and within the resistant lines carried out for 6 generations under non-sprayed field conditions showed significant yield advantages over controls. Data on pod damage and larval counts indicated that the resistance was conditioned through yield compensation mechanisms. Further studies in these lines indicated that by using the resistant genotypes, it is possible to reduce the number of insecticide sprays for economic yields [13].

Earlier studies on pod fly damage have shown that early maturing genotypes suffer more damage than the late maturing ones [17,18], and the determinate types are less susceptible than the indeterminate types $[19,20]$. However, empirical evidences reveal that long-duration varieties, in general, show heavier damage than the earlymaturing types. More than 10,000 germplasm accessions have been screened for pod fly resistance [21]. Lines with a high degree of resistance include "PDA 88-2E", "PDA 92-1E" [22], "PDA 89-2E" [23], "PDA 92-2E", "PDA 92-3E", and "PDA 93-1E" [24]. These lines can be used as the sources of resistances in the breeding programmes, and for cultivation in pod fly endemic areas. However, field observations indicate that these lines have small seed size; therefore, these may not be preferred by the pod fly for laying eggs as small sized seeds may not sustain developing larvae.

Although several studies have been reviewed on evaluation of different maturity groups of pigeonpea genotypes for resistance to pod fly [10], no definite conclusions could be drawn about the relative susceptibility of dif- 
ferent maturity groups to pod fly damage because of unstaggered flowering and variation in pod fly abundance over time [15,25]. Also very little is known about the bases and mechanisms of resistance to pod fly in pigeonpea. Therefore, it is important to identify the pod fly resistant pigeonpea genotypes, and the physico-chemical traits associated with resistance/susceptibility to pod fly from a diverse array of genotypes.

Moudgal et al. [26] characterized pigeonpea genotypes for physico-chemical pod traits imparting resistance to pod fly under field conditions. The non-determinate type "GP 75" (extra early maturing) and "GP 118" (early maturing), and determinate type "GP 233" (extra early maturing) and "GP 253" (early maturing) genotypes had significantly lower pod and seed damage as compared to early maturing checks "Prabhat" (determinate) and "Manak" (non-determinate), suggesting that resistance to pod fly is not linked to plant growth habit and maturity period of pigeonpea genotypes.

For the two other important insects namely pod sucking bugs and scale insects, available information on varietal screening is scanty. Scale insects, which are not the major pests of annual pigeonpea [5], have been reported to cause significant yield reduction $(>50 \%)$ in the sensitive genotype "IPA 11-16" of long-duration pigeonpea under field condition [14].

The above-mentioned results are based almost exclusively on the field observations. Empirical evidences do suggest that determinate cultivated types are more susceptible to pod borer and Maruca than indeterminate types. However, this differential reaction of growth habit of pigeonpea genotypes does not hold true for pod fly. Furthermore, even the genotypes rated as resistant may be "escapes" because of their maturity period and nonsynchronisation of reproductive period between host and pest. Still in other resistant genotypes, the degree of resistance may not be high, so that some proportion may be lost during its transfer and expression in different genetic backgrounds.

\section{Screening of Wild Accessions for Insect Resistance}

Wild relatives of pigeonpea are also useful sources of resistance to pod borer $[27,28]$. Wild species especially $C$. scarabaeoides $[29,30]$ and C. platycarpus [31] have been identified as the potential sources of resistance to pod borer (Table 1). Significant variation in egg-laying, numbers of larvae, and pod damage among the wild relatives of pigeonpea under field conditions have been recorded

Table 1. Morphological and biochemical traits associated with the insect resistant/tolerant and susceptible genotypes of pigeonpea*.

\begin{tabular}{|c|c|c|c|c|c|c|}
\hline SI No & Insects/biochemicals & Year & Remarks & Range & Range & References \\
\hline \multirow{2}{*}{1} & \multirow{2}{*}{$\begin{array}{l}\% \text { pod damage } \\
\text { by pod fly }\end{array}$} & 2006-07 & $\begin{array}{l}\text { Significantly higher in } \\
\text { susceptible than the } \\
\text { tolerant lines }\end{array}$ & $\begin{array}{c}14.7 \%(\mathrm{PDA} 88-2 \mathrm{E}) \text { to } \\
21.1 \% \text { (MA3) }\end{array}$ & $\begin{array}{l}30.4 \% \text { (MA24) to } \\
37.0 \% \text { (Bahar) }\end{array}$ & Srivastava et al. (1994) \\
\hline & & 2007-08 & $\begin{array}{l}\text { Significantly higher in } \\
\text { susceptible than the } \\
\text { tolerant lines }\end{array}$ & $\begin{array}{c}16.7 \%(\mathrm{PDA} 88-2 \mathrm{E}) \text { to } \\
23.4 \% \text { (MA3) }\end{array}$ & $\begin{array}{l}33.4 \% \text { (MA24) to } \\
41.6 \% \text { (Bahar) }\end{array}$ & Srivastava et al. (1994) \\
\hline \multirow{2}{*}{2} & \multirow{2}{*}{$\begin{array}{l}\% \text { grain damage } \\
\text { by pod fly }\end{array}$} & 2006-07 & $\begin{array}{l}\text { Significantly higher in } \\
\text { susceptible than the } \\
\text { tolerant lines }\end{array}$ & $\begin{array}{c}9.0 \%(\mathrm{PDA} 88-2 \mathrm{E}) \text { to } \\
14.6 \%(\mathrm{MA} 3)\end{array}$ & $\begin{array}{l}20.8 \% \text { ( MA24) to } \\
25.0 \% \text { (Bahar) }\end{array}$ & Srivastava et al. (1994) \\
\hline & & 2007-08 & $\begin{array}{l}\text { Significantly higher in } \\
\text { susceptible than the } \\
\text { tolerant lines }\end{array}$ & $\begin{array}{c}11.3 \%(\mathrm{PDA} 88-2 \mathrm{E}) \text { to } \\
13.7 \% \text { (MA3) }\end{array}$ & $\begin{array}{l}25.1 \% \text { (MA24) to } \\
30.2 \% \text { (Bahar) }\end{array}$ & Srivastava et al. (1994) \\
\hline 3 & Wax content $(\%)$ & $2007-08$ & $\begin{array}{l}\text { Significantly higher in } \\
\text { tolerant than the } \\
\text { susceptible lines }\end{array}$ & $\begin{array}{l}3.38 \% \text { (MA3) to } 4.76 \% \text { (PDA } \\
88-2 \mathrm{E})\end{array}$ & $\begin{array}{l}2.82 \% \text { (MAL 24) to } \\
2.16 \% \text { (Bahar) }\end{array}$ & Das and Odak (1987) \\
\hline 4 & $\begin{array}{l}\text { Total phenols in pod } \\
\text { walls }(\mathrm{mg} / \mathrm{g})\end{array}$ & $2007-08$ & $\begin{array}{l}\text { Significantly higher in } \\
\text { tolerant than the } \\
\text { susceptible lines }\end{array}$ & $\begin{array}{c}19.49 \mathrm{mg} / \mathrm{g}(\mathrm{PDA} 88-2 \mathrm{E}) \text { to } \\
16.24 \mathrm{mg} / \mathrm{g} \text { (MA3) }\end{array}$ & $\begin{array}{c}14.27 \mathrm{mg} / \mathrm{g} \text { (MA-24) to } \\
13.04 \mathrm{mg} / \mathrm{g} \text { (Bahar) }\end{array}$ & $\begin{array}{l}\text { Moudgal et al. (2008); } \\
\text { Sharma et al. (2009); } \\
\text { Sunitha et al. (2008) }\end{array}$ \\
\hline 5 & $\begin{array}{c}\text { Reducing } \\
\operatorname{sugars}(\mathrm{mg} / \mathrm{g})\end{array}$ & 2007-08 & $\begin{array}{l}\text { Significantly higher in } \\
\text { susceptible than the } \\
\text { tolerant lines }\end{array}$ & $\begin{array}{c}8.80 \mathrm{mg} / \mathrm{g}(\mathrm{PDA} 88-2 \mathrm{E}) \text { to } \\
13.67 \mathrm{mg} / \mathrm{g} \text { (MA3) }\end{array}$ & $\begin{array}{c}15.31 \mathrm{mg} / \mathrm{g} \\
(\mathrm{MA} \mathrm{24}) \text { to } \\
18.31 \mathrm{mg} / \mathrm{g} \text { (Bahar) }\end{array}$ & $\begin{array}{l}\text { Moudgal et al. (2008); } \\
\text { Sharma et al. (2009); } \\
\text { Sunitha et al. (2008) }\end{array}$ \\
\hline 6 & $\begin{array}{l}\text { Non-reducing } \\
\text { sugars }(\mathrm{mg} / \mathrm{g})\end{array}$ & 2007-08 & $\begin{array}{l}\text { Significantly higher in } \\
\text { susceptible than the } \\
\text { tolerant lines }\end{array}$ & $\begin{array}{c}14.95 \mathrm{mg} / \mathrm{g}(\mathrm{PDA} 88-2 \mathrm{E}) \text { to } \\
23.29 \mathrm{mg} / \mathrm{g} \text { (MA3) }\end{array}$ & $\begin{array}{l}26.16 \% \text { (MA 24) to } \\
31.08 \% \text { (Bahar) }\end{array}$ & Das and Odak (1987) \\
\hline 7 & $\begin{array}{r}\text { Total amino } \\
\text { acids }(\mathrm{mg} / \mathrm{g})\end{array}$ & 2007-08 & $\begin{array}{l}\text { Significantly higher in } \\
\text { susceptible than the } \\
\text { tolerant lines }\end{array}$ & $\begin{array}{c}1.12 \mathrm{mg} / \mathrm{g}(\mathrm{PDA} 88-2 \mathrm{E}) \text { to } \\
2.20 \mathrm{mg} / \mathrm{g} \text { (MA3) }\end{array}$ & $\begin{array}{c}2.42 \mathrm{mg} / \mathrm{g} \text { (MA-24) to } \\
4.04 \mathrm{mg} / \mathrm{g} \text { (Bahar) }\end{array}$ & Moudgal et al. (2008) \\
\hline
\end{tabular}

*Modified after Pandey et al. (2011). 
[32]. Accessions belonging to R. aurea, C. scarabaeoides, $C$. sericeus, $C$. acutifolius, and $F$. bracteata have shown high levels of resistance to pod borer, while the accessions belonging to C. cajanifolius (ICPW 28) were as susceptible to pod borer as the cultivated pigeonpea (ICPL 87). There was considerable variation in pod damage among different accessions of $C$. scarabaeoides, suggesting that it might be important to evaluate available accessions before selecting a particular accession for its utilization in breeding for resistance to insect pests. In several accessions, the numbers of eggs or larvae recorded on the marked portion of the inflorescences came to naught (zero); nevertheless, some extent of pod damage was recorded in most of the accessions tested. The pod borer moths have the choice to lay eggs also on other inflorescences (at the flowering stage) of the same plant; the larvae from the neighbouring branches migrate to others and cause pod damage, resulting in differences in egg laying, larval numbers, and pod damage.

Significant inter- and intra-species differences in the relative susceptibility to pod fly and pod wasp damage have been observed among wild accessions [33]. Accessions belonging to C. scarabaeoides, C. sericeus, Rhynchosia bracteata, C. acutifolius, C. lineatus, and C. albicans showed resistance to pod fly damage, while those from C. platycarpus, C. cajanifolius and R. aurea were susceptible. For the pod wasp, some of the accessions from C. scarabaeoides, C. albicans, Flemingia stricta, and $R$. bracteata showed resistant reaction, while "ICPW 83" (C. Scarabaeoides) showed a susceptible reaction. "ICPW 141", "ICPW 278", and "ICPW 280" (C. scarabaeoides), "ICPW 214" (R. bracteata), "ICPW 14" ( $C$. albicans), and "ICPW 202" (F. stricta) showed resistance to both pod fly and pod wasp damage. There was a negative association between pod wasp and pod borer damage; it thus appeared important to keep track of the relative susceptibility of pigeonpea genotypes to pod wasp, while breeding for resistance to pod fly [33].

From the above review, it appears that most of the wild relatives (excluding C. cajanifolius) are indeed very good sources of resistance to various insects feeding on pigeonpea. These need to be reconfirmed and exploited in breeding programme for transfer of insect resistance to the cultivated types.

\section{Morphological Markers Imparting Resistance to Insects}

Host plant resistance is an important component for minimizing the losses due to insect pests. To develop breeding strategies for resistance to insect pests, an understanding of different morphological and biochemical components of resistance is essential [32]. Association of several morphological traits such as pod toughness, struc- ture of pod wall, and trichomes on the pod surface with resistance to pod borer has been reported [30]. Some information on the nature and density of trichomes on the pods of different accessions of wild relatives of pigeonpea and their association with insect resistance, although not investigated fully, has been generated in pigeonpea and the related wild species, C. scarabaeoides [32].

Types of trichomes and their orientation, density and length have been found to influence host plant resistance/susceptibility to insect pests [32,34-37]. Trichomes and trichome exudates on the pod wall surface play an important role in the ovipositional behavior and host selection process of insect herbivores [38]. However, trichomes at times also impart susceptibility to insects like whitefly (Bemisia tabaci Gen.) in cotton [39].

Trichomes in Cajanus species have been classified as glandular $(A \& B)$ and non-glandular $(C \& D)$. Trichomes $A$ and $D$ are longer than $B$ and $C$ types, respectively. The high density of type $A$ (a characteristic feature present on the pods of cultivated types) increases the vulnerability of the host plant to pod borer to feed on the pods $[32,37]$. Dense non-glandular trichomes (type $C$ ) on pods of wild pigeonpea possibly act as a physical barrier to feeding by the young larvae of pod borer [27], while the glandular trichomes (type $A$ ) in C. cajan act as attractants [40] or phagostimulants for $H$. armigera [41]. There is an indication that the exudates from type $A$ trichome contain a feeding stimulant for the larvae [41]. The type $B$ trichome appears to give no protection against this insect. However, they are the source of characteristic pigeonpea fragrance [42]. Significantly high numbers of type $B$ trichomes were observed on the pods of $C$. lineatus, $C$. albicans, and C. cajanifolius as compared to those on the pigeonpea cultivar "ICPL 87" [32]. The fragrance of the pods of $C$. lineatus might also be due to the presence of high density of type $B$ trichomes. The contents of type $B$ trichomes are liberated only when the cell wall is ruptured, often caused by chewing actions of the insects such as pod borer or by abiotic factors such as high temperatures or low air humidity [43]. High density of trichome $C$ (5 times more than that of $C$. cajan) was present on the calyxes and pods of C. scarabaeoides. Significant negative correlations were observed for the trichome $C$ (density) with damage to buds, flowers and pods, number of eggs and larvae on the inflorescences. Although, there were a few significant negative correlations observed between type $D$ trichomes and different sites of pod borer damage, their magnitude was too low to have any significant contribution on the resistance to pod borer damage. It, therefore, appears that selection of plants bearing pods with high density of type $C$ trichome and low density of type $A$ trichomes will be useful in breeding for resistance to pod borer [37]. The presence of low density of trichome $C$ in the accessions of $C$. cajani- 
folius and cultivated species is perhaps the consequence of human directed domestication and selection.

The non-glandular trichomes, which were present at much higher densities on the wild relatives of pigeonpea than on the cultivated pigeonpea, may also act as a physical barrier to feeding by the pod borer larvae [32]. The results suggest that non-glandular trichomes (types $C$ and $D$ ) have a significant influence on genotypic susceptibility to pod borer in wild relatives of pigeonpea, and these can be used as marker traits to breed for resistance to pod borer. Expression of resistance to pod borer has also been associated with low amounts of sugars and high amounts of tannins and polyphenols. Wild accessions of pigeonpea with non-glandular trichomes (types $C$ and $D$ ) or low densities of glandular trichomes (type $A$ ), and high amounts of polyphenols and tannins may be used in wide hybridization to develop pigeonpea cultivars with resistance to $H$. armigera.

A number of morphological markers has been suggested as the basis of host plant resistance to pod fly. Singh et al. [44] observed that cultivars with thick pod wall were more resistant to pod fly. According to Moudgal et al. [26], pod wall thickness and trichome density were found to be negatively associated $\left(\mathrm{r}=-0.83^{* *}\right.$ to $\left.-0.97^{* *}\right)$ with pod fly infestation. Accordingly, they suggested to utilize these traits (trichome density and pod wall thickness) as morphological markers to identify pigeonpea genotypes with resistance to pod fly for their utilization in breeding programmes aiming at improving pod fly resistance.

It is thus obvious that selection for high density of $C$ trichomes (or low density of $A$ trichomes) will result in resistance to pod borer in pigeonpea. Similarly, pigeonpea genotypes with thick pod wall are likely to be resistant to pod fly.

\section{Biochemical Basis of Resistance to Insects}

In addition to morphological traits, biochemical constituents present in the cells and tissues of the host plant exert a profound influence on the biology of insect pests $[45,46]$. Certain biochemicals are produced by plant species in varying quantities and proportions, which affect the behaviour of phytophagous insects in various ways [47]. Chemical compounds in trichome exudates and on pod wall surface also influence the host plant selection and colonization by pod borer $[40,41,48]$. Chemicals extracted in acetone from $C$. scarabaeoides pod surface resulted in feeding inhibition, whereas compounds extracted in methanol from the pod surface of cultivated pigeonpea acted as phagostimulants [27,41]. In addition, pigeonpea also contains anti-nutritional factors such as proteinase inhibitors, oligosaccharides, phenols, tannins, and phytic acid [49], which may influence the host plant suitability to pod borer. Studies have been undertaken to ascertain the role of amounts of soluble sugars, proteins, polyphenols, and tannins in the pods of wild relatives of pigeonpea in relation to expression of resistance to pod borer [32]. Total soluble sugars were found to be higher in the pods of cultivated pigeonpea than in the wild relatives, and this may be one of the factors leading to greater feeding by $H$. armigera larvae on the pods of cultivated pigeonpea compared to that on the wild accessions [32].

MacFoy et al. [50] recorded high concentrations of sugars and amino acids in the cowpea cultivar "Vita-1", which is susceptible to spotted pod borer/Maruca. Low amounts of polyphenols in the cultivated pigeonpea might be another reason for their high susceptibility to pod borer [32]. Low amounts of phenols in pigeonpea flowers are also associated with susceptibility to spotted pod borer, M. testulalis [51]. Soluble protein content was significantly higher in the pods of $C$. Scarabaeoides than those of "ICPL 87", a cultivated variety of pigeonpea. High amounts of polyphenols were recorded in the resistant (late-maturing) wild species as compared to the cultivated pigeonpea [32]. Similar observations have also been reported earlier [52,53]. Condensed tannins in plants often act as insect growth inhibitors owing to their presumed binding to the proteins [45]. However, there is very little evidence to suggest that condensed tannins inhibit digestion in insects, but the adverse effects of condensed tannins might be due to their role as feeding deterrents [54].

The pod wall biochemical traits have been reported to play an important role in pigeonpea for resistance to insects [26]. Pigeonpea pod walls with more wax, total phenols and less reducing and non-reducing sugars and total amino acids (Table 2) suffers less pod and grain damage by pod fly [47]. Similar findings have been reported for resistance to pod fly $[26,55]$ and $H$. armigera in wild species [31], and to M. vitrata in cultivated pigeonpea [56].

\section{Mechanism of Resistance}

Ovipositional response of pod fly has been studied on resistant pigeonpea selections [57]. Regression analysis revealed that percentage oviposition and relative resistance ratings were positively correlated, and thus low seed damage was mainly due to low preference for oviposition by the pod fly. However, most of the lines, which were rated highly resistant, had small seeds. Such individual small seeds may not support and sustain the growth and development of individual eggs laid by the pod fly. This might be one of the reasons for the insects non-preference towards laying eggs on the pods of such varieties. Non-preference, however, is exclusively an in- 
Table 2. Wild species carrying resistance to insects and their crossability with $C$. cajan.

\begin{tabular}{|c|c|c|c|c|}
\hline Sl No & Resistance to insect species & Donor wild Species & Crossability with C. cajan & References \\
\hline \multirow{8}{*}{1} & \multirow{8}{*}{ Pod borer } & C. reticulatus & Crossable & Dodia et al. (1996) \\
\hline & & C. albicans & Crossable & Mallikarjuna et al. (2007) \\
\hline & & C. acutifolius & Crossable & Mallikarjuna et al. (2007) \\
\hline & & C. scarabaeoides & Crossable & Pundir and Singh (1987) \\
\hline & & C. sericeus & Crossable & Mallikarjuna et al. (2007) \\
\hline & & C. platycarpus & Crossable with embryo rescue & Mallikarjuna et al. (2006) \\
\hline & & R. bracteata & Not crossable & Mallikarjuna et al. (2007) \\
\hline & & Flemingia spp. & Not crossable & Mallikarjuna et al. (2007) \\
\hline \multirow{6}{*}{2} & \multirow{6}{*}{ Pod fly } & C. scarabaeoides & Crossable & Pundir and Singh (1987) \\
\hline & & C. albicans & Crossable & Sharma et al. (2003) \\
\hline & & C. acutifolius & Crossable & Sharma et al. (2003) \\
\hline & & C. lineatus & Crossable & Sharma et al. (2003) \\
\hline & & C. sericeus & Crossable & Sharma et al. (2003) \\
\hline & & R. bracteata & Not crossable & Sharma et al. (2003) \\
\hline 3 & Bruchids & C. sericeus & Crossable & Mallikarjuna et al. (2007) \\
\hline
\end{tabular}

sect's response that is decided purely by the presence of alternative but suitable host(s).

The wild species have antixenosis, antibiosis and nonpreferential oviposition among the various mechanisms of resistance to pod borer [28]. An accession "JM 4147" of the wild species C. scarabaeoides has been reported to possess resistance to both pod fly and the pod borer [58]. The mechanism involved for resistance was suggested as antixenosis. However, even in antixenosis, plant is avoided as the site of oviposition and habitation by the insects [59] because it is an undesirable host [60].

Antibiosis, which operates principally through production of specific bio-chemicals especially toxins in the hosts, is a true mechanism of insect resistance [60]. In pigeonpea, biochemicals such as proteinase inhibitors, low amounts of sugars and high amounts of condensed tannins, polyphenols, soluble protein [32], phytic acid [49], and the like may confer resistance to insects through antibiosis.

\section{Genetics of Resistance}

Literature abounds in information on the inheritance pattern of resistance to various insects of pigeonpea. Verulkar et al. [58] reported from their study comprising $\mathrm{F}_{1}$ (derived from a cross between a cultivated type "Pant A-3" and a wild accession "JM 4147" from C. scarabaeoides), $\mathrm{F}_{2}$, and backcross generations that the resistance (antixenosis) to pod borer is governed by a single dominant gene (Table 3). Genetics of trichome features has been studied in some detail by [37]. The two types of trichomes, $A$ (lower density) and $C$ (higher density), which impart resistance to pod borer in certain accessions of $C$. scarabaeoides, are negatively correlated $\left(-0.49^{* *}\right.$ to $\left.-0.55^{* *}\right)$ with each other. Trichomes of the wild parents (high density of the non-glandular trichomes $C$ and $D$ and glandular trichome $B$, and low density of glandular trichome $A$ ) were dominant over the trichome features of $C$. cajan. A single dominant gene as indicated by the segregation patterns individually governs each trait in the $F_{2}$ and backcross generations. Segregation ratio of 3 (resistant): 1 (susceptible) for resistance to pod borer in the $F_{2}$ generation under field conditions was corroborated with a ratio of $1: 1$ in the backcross generation, and the ratio of 1 non-segregating (resistant): 2 segregating (3 resistant: 1 susceptible): 1 non-segregating (susceptible) in the $\mathrm{F}_{3}$ generation. Resistance to pod borer and trichomes associated with it (low density of type $A$ trichome and high density of type $C$ ) are governed individually by a dominant allele of a single gene in $C$. scarabaeoides. Low damage by Helicoverpa under field conditions and low damage under no-choice laboratory conditions are also governed by dominant alleles of a single gene. The backcrossing should be used to incurporate pod borer resistance gene(s) into the adapted highyielding pigeonpea varieties [37].

Several studies have indicated simple inheritance of pod fly resistance in pigeonpea. According Verulkar et al. [58], an accession "JM 4147" of the wild species C. scarabaeoides appeared to possess resistance to both pod fly and pod borer. The results suggested that resistance to pod fly was governed by the two recessive genes. Singh and Lal [61] have reported dominance of susceptibility over resistance to pod fly with resistance being governed by the interaction of recessive and dominant alleles. According to Singh and Singh [62], however, pod fly resistance is controlled by a dominant gene in long-duration pigeonpea cultivars and suggested to incorporate it in high-yielding cultivars by simple backcrossing method. 
Table 3. Mechanism and inheritance of resistance to pod fly and pod borer in pigeonpea.

\begin{tabular}{|c|c|c|c|c|c|c|c|c|}
\hline $\begin{array}{r}\text { Sl } \\
\text { No }\end{array}$ & Insects & $\begin{array}{l}\text { Mechanism } \\
\text { of resistance }\end{array}$ & Dominant trait & Recessive trait & $\begin{array}{l}\text { Inheritance } \\
\text { of resistance }\end{array}$ & $\begin{array}{l}\text { Donors for } \\
\text { resistance }\end{array}$ & References & $\begin{array}{l}\text { Breeding approach } \\
\text { to transfer resistance } \\
\text { into pigeonpea }\end{array}$ \\
\hline 1 & Pod fly & - & $\begin{array}{l}\text { High level of } \\
\text { pod damage } \\
\text { (susceptibility) }\end{array}$ & $\begin{array}{c}\text { Low level of pod } \\
\text { damage } \\
\text { (resistance) }\end{array}$ & $\begin{array}{l}\text { Duplicate action } \\
\text { (double recessive) }\end{array}$ & $\begin{array}{l}\text { C. scarabaeoides } \\
\text { (JM 4147) }\end{array}$ & $\begin{array}{l}\text { Verulkar } \\
\text { et al. } \\
\text { (1997) }\end{array}$ & $\begin{array}{l}\text { Marker assisted } \\
\text { backcrossing } \\
\text { (MABC) }\end{array}$ \\
\hline 2 & Pod borer & $\begin{array}{c}\text { Antixenosis } \\
\text { (Non-preference) }\end{array}$ & Antixenosis & Preference & $\begin{array}{c}\text { A single } \\
\text { dominant gene }\end{array}$ & $\begin{array}{l}\text { C. scarabaeoides } \\
\text { (JM 4147) }\end{array}$ & $\begin{array}{l}\text { Verulkar } \\
\text { et al. } \\
\text { (1997) }\end{array}$ & MABC \\
\hline 3 & Pod borer & $\begin{array}{c}\text { Trichomes on pod } \\
\text { wall surface affecting } \\
\text { ovipositional } \\
\text { behavior and host } \\
\text { selection process }\end{array}$ & Resistance & Susceptible & $\begin{array}{l}\text { A single dominant } \\
\text { gene in } C . \\
\text { scarabaeoides } \\
\text { governs resistance } \\
\text { reaction }\end{array}$ & $\begin{array}{l}\text { C. scarabaeoides } \\
\text { (ICPW 94, } \\
\text { ICPW 125, } \\
\text { and ICPW 130) }\end{array}$ & $\begin{array}{l}\text { Rupakula } \\
\text { et al. } \\
\text { (2005) }\end{array}$ & MABC \\
\hline 4 & Pod borer & do & $\begin{array}{l}\text { Low density of } \\
\text { type } A \text { trichome }\end{array}$ & $\begin{array}{l}\text { High density of } \\
\text { type } A \text { trichomes } \\
\text { in } C \text {. cajan }\end{array}$ & do & $\begin{array}{l}\text { C. scarabaeoides } \\
\text { (ICPW 94, } \\
\text { ICPW 125, } \\
\text { and ICPW 130) }\end{array}$ & $\begin{array}{l}\text { Rupakula } \\
\text { et al. } \\
(2005)\end{array}$ & MABC \\
\hline 5 & Pod borer & do & $\begin{array}{l}\text { High density of } \\
\text { type } C \text { trichome }\end{array}$ & $\begin{array}{l}\text { Low density of } \\
\text { type } C \text { trichomes } \\
\text { in } C \text {. cajan }\end{array}$ & do & $\begin{array}{l}\text { C. scarabaeoides } \\
\text { (ICPW 94, } \\
\text { ICPW 125, } \\
\text { and ICPW 130) }\end{array}$ & $\begin{array}{l}\text { Rupakula } \\
\text { et al. } \\
(2005)\end{array}$ & MABC \\
\hline
\end{tabular}

The mode of inheritance for a number of traits (known to have some correlation with resistance/tolerance to insects) in pigeonpea has been investigated [63]. The results showed that pod width and phenolic content were under the control of additive genetic effects with the nonadditive effects generally being either non-significant or too small compared to the additive genetic effects. 100 seed mass was controlled by both additive and non-additive effects, while pod biochemical characteristics such as sugar content, starch content and protein content were governed by the preponderance of non-additive genetic effects.

It therefore appears that traits imparting resistance to pod borer or pod fly are under simple genetic control. These traits can be incorporated into cultivated pigeonpea through backcross breeding. Traits under additive genetic control may be improved by any selective breeding.

\section{Utilization of Wild Resources for Introgression of Resistance}

Wild relatives of pigeonpea such as $C$. scarabaeoides, $C$. sericeus, C. acutifolius, C. albicans, Rhynchosia aurea, $R$. bracteata and Flemingia bracteata have high degree of resistance to pod borer $[28,64]$. Some of the wild relatives of pigeonpea have also shown resistance to pod fly and pod wasp (Tanaostigmodes cajaninae) [28]. Advanced generation population from a cross utilizing $C$. acutifolius as the pollen parent has shown resistance to pod borer [65]. Some lines have shown a high level of resistance to pod borers, pod fly and bruchids under unprotected field conditions.

Out of the 21 wild species in the tertiary gene pool of pigeonpea, only $C$. platycarpus has been utilized for improving insect resistance through inter-specific hybridization [66,67]. It (C. platycarpus) is a species of interest to pigeonpea breeders because it has various traits of interest [31]. These include extra-early flowering and maturity, photoperiod insensitivity, prolific flowering and podding, high harvest index, annuality and rapid seedling growth including resistances to biotic stresses such as pod borer [64]. Mallikarjuna et al. [31] developed backcross progenies and obtained a range of morphological and resistance traits in the progeny lines for pod borer, bruchid, and pod fly resistance. The presence of $C$. platycarpus genome in advance generation progeny lines $\left(\mathrm{BC}_{4}\right)$ was quantified utilizing Diversity Array Technology (DArT) markers. All the derivatives were screened for resistance to pod borer, pod fly, and bruchids under unprotected field conditions. Damage in $\mathrm{BC}_{4} \mathrm{~F}_{1}$-A derivatives ranged from $6.85 \%$ to $22.84 \%$, with majority of the lines with $<15 \%$ damage. The findings with respect to resistance to insect have been summarized as per the insect species.

Progeny lines derived from C. platycarpus showed 0\% $7.44 \%$ pod borer damage compared with $14.5 \%$ damage in the control lines. Some of the lines with no bruchid damage also had significantly lower damage by pod 
borer. Three accessions of $C$. platycarpus were screened for bruchid resistance. On all the three accessions, $82 \%$ $91 \%$ of the eggs failed to hatch. Although $44 \%$ of the eggs failed to hatch on cultivar "ICPL 85010", the number of non-viable eggs on the wild species was more than double. The minimum seed damage was recorded on $C$. platycarpus accession "ICPW 66" (14\%), while the damage was moderate to medium in other $C$. platycarpus derivatives compared with the susceptible check "ICPL $85010 "$ " (75\% damage). In advance generation inter-specific derivative lines, the number of eggs that failed to hatch varied from $32.78 \%$ to $92 \%$. Although some eggs hatched, the days required for the emergence of the adult were more than in the cultivars. In most of the wild accessions as well as in the advance lines, the number of days for the adult emergence was higher. Later emergence produced smaller and weaker adults.

Low to moderate resistance was observed for the pod fly in the $\mathrm{BC}_{4} \mathrm{~F}_{1}-\mathrm{A}$ derivatives, which ranged between 4 and $22 \%$, with majority of derivatives having moderate damage between $10 \%-16 \%$, with a single derivative $\mathrm{BC}_{4} \mathrm{~F}_{1}-\mathrm{A} 15-14-1$ showing a low damage of $3.73 \%$. The line also showed low damage to pod borer (13.42\%).

In summary, high level of resistance to pod borer in the wild species can be transferred to the cultivated pigeonpea through interspecific hybridization. It is likely that mechanism(s) of resistance in wild species may be very different from those of cultivated species due to their separation in time and space during the process of evolution. These different mechanisms can be exploited to diversify the bases of resistance to H. armigera.

\section{Possibility of Developing Genotypes with Multiple Resistance to Insects}

All the above-mentioned insects cause significant economic losses in pigeonpea. Farmers cannot afford to protect the crop from multiple insects by spraying an array of chemicals as chemicals are expensive and unfriendly to the environment and to the farming community. Therefore, pigeonpea lines/varieties with multiple resistances are much desired to stabilize pigeonpea yield over seasons/years. This is achievable as there are several pigeonpea varieties with multiple resistance to diseases such as Fusarium wilt, sterility mosaic disease (SMD) and Alternaria blight [1]. Evaluation for insect resistance data showed that there is good scope to transfer multiple insect resistances from C. platycarpus to cultivated pigeonpea. A few lines with low pod borer, pod fly and bruchid damage have already been isolated [31]. It may be possible to develop pigeonpea lines having pods with high density of $C$ trichomes (low density of $A$ trichomes) and thick pod wall. Such lines could be resistant to both pod borer and pod fly.

\section{Genomic Resources for Insects Resistance}

Substantial progress has been made towards development of large-scale genomic resources in pigeonpea especially during the last decade largely due to generous financial support and coordinated efforts made by several organizations such as Indian Council of Agricultural Research (ICAR), Department of Biotechnology (DBT) of Government of India, and the like. In essence, these efforts have resulted in the development of large-scale molecular markers, construction of comprehensive genetic maps, identification of various marker-trait associations and initiation of molecular breeding in this crop. The large numbers of SSR markers [2,68,69], DArT markers [31], SNPs [70] and ESTs [68] hold high promise for improvement of a number of economic traits in pigeonpea. Availability of more than 3000 SSR markers facilitated development of inter- as well as intra-specific genetic maps using several $F_{2}$ mapping populations $[69,71]$. This represents the first instance of merging multiple genetic maps in pigeonpea. Preliminary mapping efforts for trait mapping in pigeonpea have resulted in mapping of Fusarium wilt resistance [72], SMD [73]. However, molecular breeding approaches have not yet been initiated as it may take a few more efforts to identify major QTLs for traits like FW, SMD and fertility restoration.

The much publicised draft genome sequence has also become available in pigeonpea [2,74]. Detailed analysis covering $\sim 73 \%(605.78 \mathrm{Mb})$ of the $833 \mathrm{Mbp}$ pigeonpea genome by Varshney et al. [2] has resulted in the identification of 48,680 pigeonpea genes. A few hundred of these genes were found unique to the crop in terms of drought tolerance. In another initiative by Singh et al. [74], $61 \%$ of genome was mapped. Total 47,004 protein coding genes and 12,511 transposable elements related genes were predicted. They identified 1213 disease resistance/defense response genes and 152 abiotic stress tolerance genes in the pigeonpea genome. However, genome sequences by any of the two groups did not clearly reveal/identify genes imparting resistance to major insect pests of pigeonpea.

Presence of genetic variability for resistance to insects particularly pod borer is not available in the primary gene pool of pigeonpea. Therefore, breeders need to utilize wild relatives (e.g., C. scarabaeoides, C. platycarpus) that are considered reservoirs of superior alleles for traits imparting resistance to insects that must have lost during domestication and breeding. However, transfer of desirable alleles is not so simple because of difficulty in efficient tracking for desired and non-desired alleles in breeding lines. This problem can be overcome by advancebackcross QTL based breeding (AB-breeding) as it is the most suitable for introducing novel alleles from wild relatives to the cultivated species cultivars or varieties in 
a controlled manner [75]. Initiatives are underway in this direction at national and international institutes for improving insects resistance in pigeonpea.

\section{Status of Bt Transgenics for Resistance to Helicoverpa}

Although a few lines of pigeonpea have been identified for resistance to pod borer and pod fly, the resistance has been only partial and lines with absolute resistance is not available in the cultivated germplasm [76]. Attempts to produce insect-resistant genotypes of pigeonpea by conventional breeding methods have not been much successful due to limited resistance sources in the crossable germplasm and incompatibility with wild species [77]. The advent of transgenic technology has provided the best option to improve resistance to insect pests. However, a well defined reproducible regeneration and transformation protocol is required for development of transgenics in pigeonpea.

Much effort has been directed towards developing efficient protocols for Agrobacterium- and microprojectile bombardment-based genetic transformation for this crop $[78,79]$. In pigeonpea, attempts to regenerate plants from various explants have been attempted and direct shoot induction has been obtained from various explants. These include leaves [80-82], cotyledonary node [83-85], epicotyl [86], and shoot apices $[87,88]$. However, the transformation efficiency in explants derived from cotyledonary nodes has been low [87]. More recently, shoot apices from 16-d-old seedlings were used to obtain shoot regeneration and transformation with marker genes to obtain polymerase chain reaction (PCR)-positive primary transformants of pigeonpea [88].

The advent of in planta transformation protocols in Arabidopsis gave a lead for the development of tissue culture-independent techniques in several difficult-to-regenerate species $[89,90]$. Recently, the protocol was also proved to be feasible in pigeonpea [91]. At ICRI-SAT, seedling-derived leaf explants have also been employed successfully to obtain high frequency of genetic transformation in pigeonpea through biolistics [82]. A direct shoot regeneration protocol by using the axillary bud region of the in vitro germinated seedlings as explants has been developed. A novel method for the regeneration of adventitious shoot buds and efficient transformation of pigeonpea by using Agrobacterium tumefaciens-mediated transfer of a synthetic cry $1 \mathrm{Ab}$ gene of B. thuringiensis has also been reported. Several events of transgenic pigeonpea were produced by this method that showed stable integration, inheritance, and expression of the introduced genes in subsequent generations [79]. Recently, cry $1 \mathrm{AcF}$ gene has been shown to be conferring resistance to Helicoverpa in pigeonpea [92].

As the insects also continuously try to develop resis- tance to a particular toxin gene, pyramiding of different resistance genes in transgenic plants could be a potentially more viable strategy to prevent failure of future transgenics $[93,94]$. It is also expected that the same option might help to improve the efficacy range of the introduced genes covering more than one or a set of species [95]. Because, gene pyramiding will essentially require individual transgenics to be developed first and then to combine the genes by crossing, it is essentially time consuming. An alternative to gene pyramiding would be to use synthetic genes of multiple efficacies [96]. The synergistic effect of cry $1 \mathrm{Ac}$ and $c r y 1 \mathrm{~F}$ in $1: 1$ ratio increased the toxicity of the protein 26 times [97]. The study emphasized the probability that each domain may bind to separate receptors resulting in greater efficacies [98]. Based on this, the chimeric gene, cry $1 \mathrm{AcF}$ (N-terminal and second domains from cry $1 \mathrm{Ac}$ and $\mathrm{C}$-terminal domain from $c r y 1 \mathrm{~F}$ genes were fused at $1428 \mathrm{bp}$ from the 5 ' start site) with an anticipated increase in the tolerance of the transgenic crops to a broad range of pests and this gene was shown to confer better resistance.

\section{Conclusions}

One of the main reasons for the low and unstable yield in pigeonpea is the susceptibility of the crop to a number of insects especially pod borer and pod fly. There is paucity of genotypes having resistance to these insects in the cultivated pigeonpea. The resistance traits must have been lost during the domestication and selection for highyielding plant types. Nonetheless, wild relatives of pigeonpea especially C. scarabaeoides and C. platycarpus do possess a number of morphological and biochemical traits imparting resistance to these insects. These include type and density of trichomes on pods, width of pod wall, pod walls with more wax, total phenols and low reducing and non-reducing sugars and total amino acids. These traits need to be transferred from wild relatives to the improved cultivars or advance breeding lines of pigeonpea that are deficient in resistance to these insects. However, transfer of such useful genes from the wild species is difficult through convention backcross breeding because of difficulty in efficient tracking for desired and non-desired alleles in breeding lines. Molecular breeding approaches such as marker assisted backcross (MABC), AB-breeding, and the like may be used to facilitate transfer of such useful genes from wild species.

Draft genome sequence of pigeonpea has resulted in the identification of $>47,000$ protein coding structural genes, and several hundreds of other genes concerned with defence mechanisms imparting resistance to biotic as well as abiotic stresses. However, gene sequences as claimed by both the groups have not revealed any gene(s) imparting resistance to major insects of pigeonpea. It calls for generating sequence or genotyping data further. 
Simultaneously, the pigeonpea scientists need to work on precise and cost-effective phenotyping and developing breeders-friendly databases to ensure integrated breeding approaches for improvement of resistance to insects.

Since traits/genes conferring resistance to pod borer is not available in the primary gene pool of pigeonpea, application of transgenics technology has been considered as one of the viable options to genetically mitigate the problem as it has already been exploited commercially in cotton and a few other crops. The recent advances in development and refinement of transformation and regeneration protocols are likely to yield similar results in pigeonpea also. It can be anticipated that coming years will be witnessing the integration of genomic and other molecular tools and approaches in conventional breeding programmes for improving resistance to insects in pigeonpea.

\section{REFERENCES}

[1] A. K. Choudhary and N. Nadarajan, "Breeding Improved Cultivars of Pigeonpea in India," Indian Institute of Pulses Research (IIPR), Kanpur, 2011, pp. 1-30.

[2] R. K. Varshney, W. Chen, Y. Li, A. K. Bharti, R. K. Saxena, J. A. Schlueter, et al., "Draft Genome Sequence of Pigeonpea (Cajanus cajan), an Orphan Legume Crop of Resource-Poor Farmers," Nature Biotechnology, Vol. 30, No. 1, 2012, pp. 83-89. doi:10.1038/nbt.2022

[3] FAO, "FAOSTAT," FAO, Rome, 2009.

http://faostat.fao.org/site/567/DesktopDefault.aspx?PageI $\mathrm{D}=567$ \#ancor

[4] A. K. Choudhary, R. Sultana, A. Pratap, N. Nadarajan and U. C. Jha, "Breeding for Abiotic Stresses in Pigeonpea," Journal of Food Legumes, Vol. 24, No. 3, 2011, pp. 165-174.

[5] G. V. Ranga Rao and T. G. Shanower, "Identification and Management of Pigeonpea and Chickpea Insect Pests in Asia," International Crops Research Institute for the SemiArid Tropics, Hyderabad, 1999.

[6] ICRISAT, “The Medium Term Plan," Vol. 1, 1992, International Crop Research Institute for the Semi-Arid Tropics, Patancheru, India.

[7] M. K. Tripathi and H. N. Singh, "Mechanisms of Pyrethroids Resistance in the Larvae of Helicoverpa armigera (Hubner) Collected from Three Different Agroclimatic Zones of India," Journal of Entomological Research, Vol. 24, No. 1, 2000, pp. 9-18.

[8] Vishwadhar, S. K. Singh, T. P. Trivedi, D. K. Das, A. Dhandapani, R. G. Chaudhary and M. Kumar, "Forecasting of Helicoverpa armigera Infestation on LongDuration Pigeonpea in Central Uttar Pradesh," Journal of Food Legumes, Vol. 21, No. 3, 2008, pp. 189-192.

[9] M. Deepa and C. P. Srivastava, "Genetic Diversity in Helicoverpa armigera (Hübner) from Different Agroclimatic Zones of India Using RAPD Markers," Journal of Food Legumes, Vol. 24, No. 4, 2011, pp. 313-316.

[10] T. G. Shanower, S. S. Lal and R. Bhagwat, "Biology and
Management of Melanagromyza obtusa (Malloch) (Diptera: Agromyzidae)," Crop Protection, Vol. 17, No. 3, 1998, pp. 249-263. doi:10.1016/S0261-2194(97)00117-8

[11] O. S. Srivastava, "Estimation of Loss in T 21 Variety of Arhar (Cajanus cajan L.) Due to 'Tur' Pod Xy (Melanagromyza obtusa Malloch)," Indian Journal of Entomology, Vol. 34, No. 1, 1972, pp. 82-83.

[12] T. G. Shanower, J. Romeis and E. M. Minja, "Insect Pests of Pigeon Pea and Their Management," Annual Review Entomology, Vol. 44, 1999, pp. 77-96. doi:10.1146/annurev.ento.44.1.77

[13] K. B. Saxena, G. D. S. N. Chandrasena, K. Hettiarachchi, Y. B. Iqbal, H. H. D. Fonseka and S. J. B. A. Jayasekera, "Evaluation of Pigeonpea Accessions and Selected Lines for Reaction to Maruca," Crop Science, Vol. 42, No. 2, 2002, pp. 615-618. doi:10.2135/cropsci2002.0615

[14] A. K. Choudhary, P. Duraimurugan and J. Kumar, "Heavy Infestation of Scale Insect in Late Pigeonpea," Pulses Newsletter (IIPR), Vol. 22, No. 2, 2011, p. 4.

[15] S. S. Lateef and W. Reed, "Insect Pests on Pigeonpea," In: S. R. Singh, Ed., Insect Pests of Tropical Food Legumes, John Wiley \& Sons Ltd, Chichester, 1990, pp. 193-242.

[16] S. S. Lateef, "Scope and Limitations of Host Plant Resistance in Pulses for the Control of Helicoverpa armigera," In: J. N. Schan, Ed., Helicoverpa Management: Current Status and Future Strategies, Indian Institute of Pulses Research, Kanpur, 1992, pp. 31-37.

[17] D. J. Bhosale and R. N. Nawale, "Field Screening of Pigeonpea Germplasm against Pod Fly Melangromyza obtusa (Malloch)," Indian Journal of Entomology, Vol. 47 (Part 1), 1985, pp. 92-97.

[18] S. S. Lal, C. P. Yadav and J. N. Sachan, "Studies on Some Aspects of Oviposition and Damage of Pod Fly in Relation to the Host Phenology," Indian Journal of Pulses Research, Vol. 1, 1988, pp. 83-88.

[19] S. S. Lal, C. P. Yadav and S. Chandra, "Suppression of Pod Fly Damage through Varietal Selection," International Pigeonpea Newsletter, Vol. 5, 1986, pp. 42-43.

[20] S. C. Gupta, S. S. Lateef and R. P. Ariyanayagam, "Are Determinates Inferior to Indeterminates in Short-Duration Pigeonpea?" International Pigeonpea Newsletter, Vol. 13, 1991, pp. 11-13.

[21] S. S. Lateef and M. P. Pimbert, "The Search for Post Plant Resistance to Helicoverpa armigera in Chickpea and Pigeonpea at ICRISAT," Summary Proceedings of the First Consultative Group Meeting on Host Selection Behavior of Heliothis armigera, International Crops Research Institute for the Semi-Arid Tropics, Patancheru, 1990, pp. 25-28.

[22] C. Durairaj and N. Ganapathy, "Evaluation of Pigeonpea (Cajanus cajan) Entries of Late-Maturity Group for Tolerance to Pod Borers (Helicoverpa armigera, Maruca testulalis) and Pod Fly (Melanagromyza obtusa)," Indian Journal of Agricultural Sciences, Vol. 67, No. 8, 1997, pp. 317-318.

[23] C. P. Srivastava, R. Raina and R. M. Singh, "Screening of Promising Pigeonpea Lines against Pod Fly and PodSucking Bugs at the Banaras Hindu University, Varanasi, 
Uttar Pradesh, India," International Chickpea and Pigeonpea Newsletter, Vol. 1, 1994, pp. 41-42.

[24] S. S. Lal and Y. S. Rathore, "Host Plant Resistance to Pod Fly (Melanagromyza obtusa) in Pigeonpea (Cajanus cajan)," Indian Journal of Agricultural Sciences, Vol. 71, No. 8, 2001, pp. 531-534.

[25] H. K. Singh and H. N. Singh, "Screening of Certain Pigeonpea Cultivars Sown at Kharif and Rabi Crops against Tur Pod Bug, Clavigralla gibbosa and Pod Xy, Melanagromyza obtusa," Indian Journal of Entomology, Vol. 52, No. 2, 1990, pp. 320-327.

[26] R. K. Moudgal, R. K. Lakra, B. Dahiya and M. K. Dhillon, "Physico-Chemical Traits of Cajanus cajan (L.) Millsp. Pod Wall a Vecting Melanagromyza obtusa (Malloch) Damage," Euphytica, Vol. 161, No. 3, 2008, pp. 429436. doi:10.1007/s10681-007-9601-5

[27] J. Romeis, T. G. Shanower and A. J. Peter, "Trichomes on Pigeonpea [Cajanus Cajan (L.) Millsp.] and Two Wild Cajanus Spp," Crop Science, Vol. 39, No. 2, 1999, pp. 564-569. doi:10.2135/cropsci1999.0011183X003900020043x

[28] H. C. Sharma, P. W. C. Green, P. C. Stevenson and M. S. J. Simmonds, "What Makes It Tasty for the Pest? Identification of Helicoverpa armigera (Hubner) Feeding Stimulants and Location of Their Production on the PodSurface of Pigeonpea [Cajanus cajan (L.) Millsp.]," Competitive Research Facility Project R7029 C, Final Technical Report, Department for International Development, London, 2001.

[29] R. P. S. Pundir and R. B. Singh, "Possibility of Genetic Improvement in Pigeonpea Utilising the Wild Genetic Resourses," Euphytica, Vol. 36, No. 1, 1987, pp. 33-37. doi:10.1007/BF00730644

[30] T. G. Shanower, M. Yoshida and A. J. Peter, "Survival, Growth, Fecundity and Behavior of Helicoverpa armigera (Lepidoptera: Noctuidae) on Pigeonpea and Two Wild Cajanus Species," Journal of Economic Entomology, Vol. 90, No. 3, 1997, pp. 837-841.

[31] N. Mallikarjuna, S. Senapathy, D. R. Jadhav, K. B. Saxena, H. C. Sharma and H. D. Upadhyaya, "Progress in the Utilization of Cajanus platycarpus (Benth.) Maesen in Pigeonpea Improvement," Plant Breeding, Vol. 130, No. 5, 2011, pp. 507-514. doi:10.1111/j.1439-0523.2011.01870.x

[32] H. C. Sharma, E. G. Sujana and E. D. Manohar Rao, "Morphological and Chemical Components of Resistance to Pod Borer, Helicoverpa armigera in Wild Relatives of Pigeonpea," Arthropod-Plant Interactions, Vol. 3, No. 3, 2009, pp. 151-161. doi:10.1007/s11829-009-9068-5

[33] H. C. Sharma, G. Pampathy and L. J. Reddy, "Wild Relatives of Pigeonpea as a Source of Resistance to the Pod Fly and Pod Wasp," Genetic Resources and Crop Evolution, Vol. 50, No. 8, 2003, pp. 817-824. doi:10.1023/A:1025967528757

[34] C. E. Jeffree, "The Cuticle, Epicuticular Waxes and Trichomes of Plants, with Reference to Their Structure, Functions and Evolution," In: B. E. Juniper and T. R. E. Southwood, Eds., Insects and the Plant Surface, Edward Arnold Publishers Ltd., London, 1986, pp. 23-64.
[35] A. J. Peter, T. G. Shanower and J. Romeis, "The Role of Plant Trichomes in Insect Resistance: A Selective Review," Phytophaga, Vol. 7, 1995, pp. 41-64.

[36] P. L. Valverde, J. Fornoni and J. Nunez-Farfan, "Defensive Role of Leaf Trichomes in Resistance to Herbivorous Insects in Datura stramonium," Journal of Evolutionary Biology, Vol. 14, No. 3, 2001, pp. 424-432. doi:10.1046/j.1420-9101.2001.00295.x

[37] R. Aruna, M. Rao, L. J. Reddy, H. D. Upadhyaya and H. C. Sharma, "Inheritance of Trichomes and Resistance to Pod Borer (Helicoverpa armigera) and Their Association in Interspecific Crosses between Cultivated Pigeonpea (Cajanus cajan) and Its Wild Relative C. scarabaeoides," Euphytica, Vol. 145, No. 3, 2005, pp. 247-257. doi:10.1007/s10681-005-1643-y

[38] E. A. Bernays, R. F. Chapman and M. S. Singer, "Sensitivity to Chemically Diverse Phagostimulants in a Single Gustatory Neuron of a Polyphagous Caterpillar," Journal of Comparative Physiology, Vol. 186, No. 1, 2000, pp. 13-19. doi:10.1007/s003590050002

[39] C. C. Chu, E. T. Natwick and T. J. Hanneberry, "Susceptibility of Normal-Leaf and Okra-Leaf Shape Cottons to Silver Leaf Whiteflies and Relationships to Trichome Densities," In: D. J. Herber and D. A. Richter, Eds., Proceedings of the Beltwide Cotton Production Research Conference, San Antonio, National Cotton Council of America, Memphis, 2000, pp. 1157-1158.

[40] E. Hartlieb and H. Rembold, "Behavioral Response of Female Helicoverpa (Heliothis) armigera (Hub.) (Lepidoptera: Noctuidae) Moths to Synthetic Pigeonpea ( $\mathrm{Ca}$ janus cajan L.) Kairomone," Journal Chemical Ecology, Vol. 22, No. 4, 1996, pp. 821-837. doi:10.1007/BF02033589

[41] P. W. C. Green, P. C. Stevenson, M. S. J. Simmonds and H. C. Sharma, "Phenolic Compounds on the Pod Surface of Pigeonpea, Cajanus cajan, Mediate Feeding Behavior of Larvae of Helicoverpa armigera," Journal of Chemical Ecology, Vol. 29, No. 4, 2003, pp. 811-821. doi:10.1023/A:1022971430463

[42] S. S. Bisen and A. R. Sheldrahe, "The Anatomy of the Pigeonpea," Research Bulletin No. 5, 1981, International Crop Research Institute for the Semi-Arid Tropics (ICRISAT), Patancheru.

[43] L. Ascensao, N. Marques and M. S. Pais, "Glandular TriChomes on Vegetative and Reproductive Organs of Leonotis leonurus (La-Maiacez)," Annals of Botany, Vol. 75, No. 6, 1995, pp. 619-626. doi:10.1006/anbo.1995.1067

[44] O. Singh, U. P. Singh, M. N. Singh and M. C. Jain, "Effects of Pod Wall Thickness on Pod Fly Susceptibility in Pigeonpea [Cajanus cajan (L.) Millsp.]," Journal of Applied Biology, Vol. 12, No. 1-2, 2002, pp. 7-8.

[45] C. M. Smith, "Plant Resistance to Insects: A Fundamental Approach," Wiley, New York, 1989.

[46] H. C. Sharma, "Applications of Biotechnology in Pest Management and Ecological Sustainability," CRC Press Taylor and Francis, Boca Raton, 2009, p. 526.

[47] V. Pandey, C. P. Srivastava, N. Triyugi and P. Raha, "Chemical Traits of Pigeonpea (Cajanus cajan) Pod Wall Affecting Pod Fly (Melanagromyza obtuse) Damage," In- 
dian Journal of Agricultural Sciences, Vol. 81, No. 11, 2011, pp. 1059-1062.

[48] P. W. C. Green, P. C. Stevenson, M. S. J. Simmonds and H. C. Sharma, "Can Larvae of the Pod-Borer, Helicoverpa armigera (Lepidoptera: Noctuidae), Select between Wild and Cultivated Pigeonpea [Cajanus spp. (Fabaceae)]," Bulletine Entomology Research, Vol. 92, No. 4, 2002, pp. 45-51.

[49] U. Singh, "Antinutritional Factors of Chickpea and Pigeonpea and Their Removal by Processing," Plant Foods for Human Nutrition, Vol. 38, No. 3, 1988, pp. 251-261. doi:10.1007/BF01092864

[50] C. A. MacFoy, Z. T. Dabrowski and S. Okech, "Studies on the Legume Pod Borer Maruca testulalis (Geyer)—VI. Cowpea Resistance to Oviposition and Larval Feeding," Insect Science Application, Vol. 4, No. 1-2, 1983, pp. 147152.

[51] N. Ganapathy, "Bio-Ecology and Management of Spotted Pod Borer (Maruca testulalis Geyer) in Pigeonpea," Ph.D. Thesis, Tamil Nadu Agricultural University, Coimbatore, 1996, pp. 1-171.

[52] G. R. Murkute, A. R. Dhage, B. B. Desai, A. A. Kale, U. N. Mote and R. P. Aher, "Biochemical Parameters Associated with Pod Borer Damage as Influenced by Maturity Group and Growth Stages of Pigeonpea [Cajanus cajan (L.)] Millsp," Legume Research, Vol. 16, No. 2, 1993, pp. 151-156.

[53] B. K. Sahoo and H. P. Patnaik, "Effect of Biochemicals on the Incidence of Pigeonpea Pod Borers," Indian Journal of Plant Protection, Vol. 31, No. 1, 2003, pp. 105108.

[54] J. S. Martin, M. M. Martin and E. A. Bernays, "Failure of Tannic Acid to Inhibit Digestion or Reduce Digestibility of Plant Protein in Gut Fluids of Insect Herbivores," Journal of Chemical Ecology, Vol. 13, No. 3, 1987, pp. 605-621. doi:10.1007/BF01880103

[55] S. B. Das and S. C. Odak, "Biochemical Basis of Resistance in Pigeonpea Pod Walls to Pod Fly, Melanagromysa obtusa (Malloch)," Indian Journal of Entomology, Vol. 47, 1987, pp. 92-97.

[56] V. Sunitha, G. V. Ranga Rao, K. Vijaya Lakshmi, K. B. Saxena, V. R. Rao and Y. V. R. Reddy, "Morphological and Biochemical Factors Associated with Resistance to Maruca Vitriata in Short Duration Pigeonpea," International Journal of Tropical Sciences, Vol. 28, No. 1, 2008, pp. 45-52.

[57] S. S. Lal and C. P. Yadava, "Ovipositional Response of Pod Fly (Melanagromyza obtusa) on Resistant Pigeonpea (Cajanus cajan) Selections," Indian Journal of Agricultural Sciences, Vol. 64, No. 9, 1994, pp. 317-318.

[58] S. B. Verulkar, D. P. Singh and A. K. Bhattacharya, "Inheritance of Resistance to Podfly and Podborer in the Interspecific Cross of Pigeonpea," Theoretical and Applied Genetics, Vol. 95, No. 3, 1997, pp. 506-508. doi: $10.1007 / \mathrm{s} 001220050590$

[59] M. Kogan and E. E. Ortman, "Antixenosis: A New Term Proposed to Replace Painter's Non-Preference Modality of Resistance," Eastern Southern Africa Bulletine, Vol. 24, No. 2, 1978, pp. 175-176.
[60] A. K. Choudhary and A. G. Vijayakumar, "Glossary of Plant Breeding, A Perspective," LAP LAMBERT Academic Publishing, Saarbrücken, 2012.

[61] I. P. Singh and S. S. Lal, "Inheritance of Rersistance to Podfly in Pigeonpea (Cajanus cajan L. Millsp)," Journal of Genetics and Breeding, Vol. 56, No. 1, 2002, pp. 8588.

[62] I. P. Singh, P. K. Katiyar and S. K. Singh, "Inheritance of Genes Imparting Resistance to Pod Fly (Melanagromyza obtusa) in Pigeonpea (Cajanus cajan)," Indian Journal of Agriculture Sciences, Vol. 79, No. 8, 2009, pp. 628-631.

[63] A. Beekham and P. Umaharan, "Inheritance and Combining Ability Studies of Pod Physical and Biochemical Quality Traits in Vegetable Pigeonpea (Cajanus cajan L. Millsp)," Euphytica, Vol. 176, No. 1, 2010, pp. 37-47. doi:10.1007/s10681-010-0211-2

[64] G. Sujana, H. C. Sharma and D. M. Rao, "Antixenosis and Antibiosis Components of Resistance to Pod Borer Helicoverpa armigera in Wild Relatives of Pigeonpea," International Journal Tropical Insect Science, Vol. 28, No. 4, 2008, pp. 191-200.

[65] N. Mallikarjuna, H. C. Sharma and H. D. Upadhyaya, "Exploitation of Wild Relatives of Pigeonpea and Chickpea for Resistance to Helicoverpa armigera," SAT $e$ Journal, Vol. 3, No. 1, 2007, pp. 1-4.

[66] N. Mallikarjuna and J. P. Moss, "Production of Hybrids between Cajanus platycarpus and C. cajan," Euphytica, Vol. 83, No. 1, 1995, pp. 43-46. doi:10.1007/BF01677859

[67] N. Mallikarjuna, D. Jadhav and P. Reddy, "Introgression of Cajanus platycarpus Genome into Cultivated Pigeonpea, C. cajan," Euphytica, Vol. 149, No. 1-2, 2006, pp. 161167. doi:10.1007/s10681-005-9063-6

[68] N. L. Raju, B. N. Gnanesh, P. Lekha, B. Jayashree, S. Pande and P. J. Hiremath, "The First Set of EST Resource for Gene Discovery and Marker Development in Pigeonpea (Cajanus cajan L.)," BMC Plant Biology, Vol. 10, 2010, p. 45. doi:10.1186/1471-2229-10-45

[69] A. Bohra, A. Dubey, R. K. Saxena, R. V. Penmetsa, K. N. Poornima and N. Kumar, "Analysis of BAC-End Sequences (BESs) and Development of BES-SSR Markers for Genetic Mapping and Hybrid Purity Assessment in Pigeonpea (Cajanus spp.)," BMC Plant Biology, Vol. 11, No. 3, 2011, p. 15. doi:10.1186/1471-2229-11-56

[70] A. Dubey, A. Farmer, J. Schlueter, S. B. Cannon, B. Abernathy and R. Tuteja, "Defining the Transcriptome Assembly and Its Use for Genome Dynamics and Transcriptome Profiling Studies in Pigeonpea (Cajanus cajan L.)," DNA Research, Vol. 18, No. 3, 2011, pp. 153-164. doi:10.1093/dnares/dsr007

[71] A. Bohra, R. K. Saxena, B. N. Gnanesh, et al., "An Intra-Specific Consensus Genetic Map of Pigeonpea [Cajanus cajan (L.) Millspaugh] derived from Sixmapping Populations," Theoretical and Applied Genetics, Vol. 125, No. 6, 2012, pp. 1325-1338.

doi:10.1007/s00122-012-1916-5

[72] H. Kotresh, B. Fakrudin, S. Punnuri, B. Rajkumar, M. Thudi and H. Paramesh, "Identification of Two RAPD Markers Genetically Linked to a Recessive Allele of a Fusarium Wilt Resistance Gene in Pigeonpea (Cajanus 
cajan (L.) Millsp.)," Euphytica, Vol. 149, No. 1-2, 2006, pp. 113-120. doi:10.1007/s10681-005-9059-2

[73] K. N. Ganapathy, B. Gowda, S. C. Venkatesh, R. Ramachandra, B. N. Gnanesh and G. Girish, "Identification of AFLP Markers Linked to Sterility Mosaic Disease in Pigeonpea [Cajanus cajan (L.) Millsp.]," International Journal of Integrative Biology, Vol. 7, No. 3, 2010, pp. 145149.

[74] N. K. Singh, D. K. Gupta, P. K. Jayaswal, A. K. Mahato, S. Dutta, et al., "The First Draft of the Pigeon Pea Genome Sequence," Journal of Plant Biochemistry and Biotechnology, Vol. 21, No. 1, 2012, pp. 98-112. doi:10.1007/s13562-011-0088-8

[75] S. D. Tanksley and J. C. Nelson, "Advanced Backcross QTL Analysis: A Method for the Simultaneous Discovery and Transfer of Valuable QTLs from Unadapted Germplasm into Elite Breeding Lines," Theoretical and Applied Genetics, Vol. 92, No. 2, 1996, pp. 191-203. doi:10.1007/BF00223376

[76] A. Grover and D. Pental, "Breeding Objectives and Requirements for Producing Transgenics for Major Field Crops of India," Current Science, Vol. 84, No. 3, 2003, pp. 310-320.

[77] Y. L. Nene and V. K. Sheila, "Pigeonpea: Geography and Importance," In: Y. L. Nene, S. D. Hall, V. K. Sheila, Eds., The Pigeonpea, CAB International, Wallingford, 1990, pp. $1-14$.

[78] M. R. Surekha Beena, A. Arundhati, P. K. Singh, R. Tuli, A. Dutta-Gupta and P. B. Kirti, "Agrobacterium-Mediated Genetic Transformation of Pigeon Pea (Cajanus cajan (L.) Millsp.) Using Embryonal Segments and Development of Transgenic Plant for Resistance against Spodoptera," Plant Science, Vol. 169, No. 6, 2005, pp. 10741080. doi:10.1016/j.plantsci.2005.07.011

[79] K. K. Sharma, M. Lavanya and V. Anjaiah, "Agrobacterium Mediated Production of Transgenic Pigeon Pea (Cajanus cajan L., Millsp) Expressing the Synthetic crylab gene," In Vitro Cell Development and BiologyPlant, Vol. 42, No. 2, 2006, pp. 165-173.

[80] S. Eapen and L. George, "Plant Regeneration from Leaf Discs of Peanut and Pigeonpea: Influence of Benzyladenine, Indoleacetic Acid and Indoleacetic Acid-Amino Acid Conjugates," Plant Cell Tissue Organ Culture, Vol. 35, No. 3, 1993, pp. 223-227. doi:10.1007/BF00037274

[81] N. Geetha, P. Venkatachalam, V. Prakash and G. LakshmiSita, "High Frequency Induction of Multiple Shoots and Plants Regeneration from Seedling Explants of Pigeonpea (Cajanus cajan L.)," Current Science, Vol. 75, No. 10, 1998, pp. 1036-1041.

[82] S. Dayal, M. Lavanya, P. Devi and K. K. Sharma, "An Efficient Protocol for Shoot Regeneration and Genetic Transformation of Pigeonpea (Cajanus cajan (L.) Millsp.) by Using Leaf Explants," Plant Cell Reports, Vol. 21, No. 11, 2003, pp. 1072-1079. doi:10.1007/s00299-003-0620-y

[83] N. S. Prakash, D. Pental and N. Bhalla-Sarin, "Regeneration of Pigeonpea (Cajanus cajan) from Cotyledonary Node via Multiple Shoots Formation," Plant Cell Reports, Vol. 13, No. 11, 1994, pp. 623-627.

doi:10.1007/BF00232933
[84] M. L. Mohan and K. V. Krishnamurthy, "Plant Regeneration in Pigeonpea (Cajanus cajan (L.) Millsp.) by Organogenesis," Plant Cell Reports, Vol. 17, No. 9, 1998, pp. 705-710. doi:10.1007/s002990050469

[85] N. D. Singh, L. Sahoo, Sonia and P. K. Jaiwal, "In Vitro Shoot Organogénesis and Plant Regeneration from Cotyledonary Node and Leaf Explants of Pigeonpea (Cajanus cajan L. Millsp.)" Physiology and Molecular Biology of Plants, Vol. 8, No. 1, 2002, pp. 133-140.

[86] S. Eapen, S. Tivarkar and L. George, "Thidiazuron Induced Shoot Regeneration in Pigeonpea (Cajanus cajan L.)," Plant Cell Tissue Organ Culture, Vol. 53, No. 3, 1998, pp. 217-220. doi:10.1023/A:1006060318752

[87] N. Geetha, P. Venkatachalam and G. LakshmiSita, “Agrobacterium-Mediated Genetic Transformation of Pigeonpea (Cajanus cajan L.) and Development of Transgenic Plants via Direct Organogenesis," Plant Biotechnology, Vol. 16, No. 3, 1999, pp. 213-218. doi:10.5511/plantbiotechnology.16.213

[88] N. D. Singh, L. Sahoo, R. Saini, N. B. Sarin and P. K. Jaiwal, "In Vitro Regeneration and Recovery of Primary Transformants from Shoot Apices of Pigeonpea Using Agrobacterium tumefaciens," Physiology and Molecular Biology of Plants, Vol. 10, No. 1, 2004, pp. 65-74.

[89] M. I. Chumakov, N. A. Rozhok, V. A. Velicov, V. S. Tyrnov and I. V. Volokhina, "Agrobacterium-Mediated in Planta Transformation of Maize via Pistil Filaments," Russian Journal of Genetics, Vol. 42, No. 8, 2006, pp. 893897. doi:10.1134/S1022795406080072

[90] P. Supartana, T. Shimizu, M. Nogawa, H. Shioiri, T. Nakajima, N. Haramoto, M. Nozue and M. Kojima, "Development of Simple and Efficient in Planta Transformation Method for Wheat (Triticum aestivum L.) Using Agrobacterium tumefaciens," Journal of Bioscience and Bioengeering, Vol. 102, No. 3, 2006, pp. 162-170. doi: $10.1263 / \mathrm{jbb} .102 .162$

[91] K. S. Rao, R. Sreevathsa, P. D. Sharma, E. Keshamma, M. Udaya Kumar, "In Planta Transformation of Pigeon Pea: A Method to Overcome Recalcitrancy of the Crop to Regeneration," Physiology and Molecular Biology of Plants, Vol. 14, No. 4, 2008, pp. 321-328. doi:10.1007/s12298-008-0030-2

[92] S. V. Ramu, S. Rohini, G. Keshavareddy, M. Gowri Neelima, N. B. Shanmugam, A. R. V. Kumar, S. K. Sarangi, P. Ananda Kumar and M. Udayakumar, "Expression of a synthetic cry $1 \mathrm{AcF}$ Gene in Transgenic Pigeon pea Confers Resistance to Helicoverpa armigera," Journal of Applied Entomology, Vol. 136, No. 9, 2012, pp. 675-687. doi:10.1111/j.1439-0418.2011.01703.x

[93] J. T. Greenplate, S. R. Penn, Z. Shappley, M. Oppenhuizen, J. Mann, J. Reich and J. Oshorn, "Bollgard II Efficacy: Quantification of Total Lepidopteran Activity in a Two Gene Product," Proceedings of Belt Wide Cotton Conference, Vol. 2, 2000, pp. 1041-1043.

[94] J. Cao, J. Z. Zhao, A. M. Shelton and E. D. Earle, "Broccoli Plants Pyramided with $c r y 1 A C$ and $c r y 1 C$ Bt Gene Control Diamondback Moths Resistance to $c r y 1 A$ and cry $1 A C$ Proteins," Theoretical and Applied Genetics, Vol. 105, No. 2, 2002, pp. 258-264. 


$$
\text { doi:10.1007/s00122-002-0942-0 }
$$

[95] K. Datta, N. Baisakh, K. M. Thet, J. Tu and S. K. Datta, "Pyramiding Transgenes for Multiple Resistance in Rice against Bacterial Blight, Stem Borer and Sheath Blight," Theoretical and Applied Genetics, Vol. 106, No. 1, 2002, pp. 1-8.

[96] S. Naimov, S. Dukiandjiev, A. Ruud and M. De, “A Hybrid Bacillus thuringiensis Delta-Endotoxin Gives Resistance against a Coleopteran and a Lepidopteran Pest in Transgenic Potato," Journal of Plant Biotechnology, Vol. 1, No. 1, 2003, pp. 51-57.
[97] S. K. Chakrabarti, A. Mandaokar, P. A. Kumar and R. P. Sharma, "Efficacy of Lepidopteran Specific $\delta$-Endotoxins of Bacillus thuringiensis against Helicoverpa armigera," Journal of Invertebrate Pathology, Vol. 72, No. 3, 1998, pp. 336-337. doi:10.1006/jipa.1998.4786

[98] S. K. Chakrabarti, A. Mandaokar, P. A. Kumar and R. P. Sharma, "Synergistic Effect of cry1Ac and cry $1 \mathrm{~F} \delta$ Endotoxins of Bacillus thuringiensis on Cotton Bollworm, Helicoverpa armigera," Current Science, Vol. 75, No. 7, 1998, pp. 663-664. 